\title{
Climate Change and the German Law of Torts
}

\author{
Philipp Semmelmayer ${ }^{1}$ \\ ${ }^{1}$ Friedrich-Alexander University Erlangen-Nürnberg, Erlangen, Germany \\ Corresponding author: philipp.semmelmayer@fau.de
}

(Received 11 August 2020; accepted 16 November 2020)

\begin{abstract}
Even throughout a global pandemic, climate change continues to be a fiercely discussed topic-both politically and legally - the world over. Particularly in light of the many Covid-19 related financial aid programs (including transnational ones) and the associated economic stabilization and reconstruction plans, a sustainable climate policy and legal order should be expected to play a role for an economy that has fallen into a slump. Nevertheless, a lively discussion on how best to achieve climate protection continues to take place in already established systems such as the private law system. Here, as far as climate change is concerned, tort law appears to be the focus of these discussions. The extent to which tort law and the issue of climate change can be brought together is also increasingly being discussed in Germany. This article attempts to shed light on the questions of how tort law could contribute to the mitigation of climate change and how climate change could fit into the law of torts of the German civil law legal system.
\end{abstract}

Keywords: Climate Change; Environmental Law; Tort Law; Climate Litigation; Lliuya v RWE AG

\section{A. Introduction}

In many countries around the world, attempts-primarily through public law-are being made to deal with the problem of climate change, as climate change affects the population as a whole. But the legal debate on how to tackle climate change is also increasing in private law, primarily through the law of torts. It is disputed, however, if and how climate change can be integrated into the regulatory system of tort law. Thus, climate change has been described as the "paradigmatic anti-tort" due to its "diffuse and disparate" origins and its "lagged and latticed" effect; "a collective action problem so pervasive and so complicated as to render at once both all of us and none of us responsible."1 In Germany, the debate is fueled by the fact that the German legislation and jurisdiction have very recently addressed the issue of climate change. At the end of 2019, the German Bundestag (German Parliament) passed the Bundes-Klimaschutzgesetz (Federal Climate Protection Act) which has since been ruled insufficient by the Bundesverfassungsgericht (German Federal Constitutional Court). ${ }^{2}$ From the perspective of the Bundestag, however, tort

Philipp Semmelmayer, LL.M. (Auckland) is a PhD student and research assistant at the Institute of Legal History and Chair of Civil Law, German and European Legal History (Professor Dr. Bernd Mertens) at the above University in Erlangen. The author thanks Professor Jason W. Neyers (University of Western Ontario) for the inspiration and support in the writing of this article.

${ }^{1}$ For detailed criticism, see Douglas A. Kysar, What Climate Change Can Do About Tort Law, 41 J. EnV'T L. 1, 4 (2011); Asia Pacific Judicial Colloquium on Climate Change, 109 (2019).

${ }^{2}$ Bundesverfassungsgericht [BVerfG] [Federal Constitutional Court] Mar. 24, 2021, 1 BvR 2656/18, https://www. bundesverfassungsgericht.de/SharedDocs/Entscheidungen/EN/2021/03/rs20210324_1bvr265618en.html. 
law remains a marginal matter at best, even though it could be instrumental in many respects in the fight against climate change.

The question as to what and how tort law could contribute to the mitigation of climate change is interesting in that tort law - in contrast to public law - is dominated by individual rights, interests, and relationships. Thus, above all, tort law is ruled by an economic frame of thinking instead of a 'green' one. Nevertheless, tort law might play a role, especially where the current legal frameworks cannot offer a just and sufficient solution to the extremely complex issue of climate change. ${ }^{3}$ Tort law could interact with public climate change law in a way that both will benefit the climate. In this way, public law clarifies what the tort system can and cannot achieve and informs what it should and should not achieve. Furthermore, in addressing alleged injuries to the climate, tort law might -indirectly-guide the legislative and executive branches as to where action is required to fashion a legal remedy. ${ }^{4}$ In addition, in tort litigation, courts speak not only to the litigants before them-and future litigants - but potentially also beyond tort law and beyond their jurisdiction. ${ }^{5}$ And tort law disputes have further advantages. For example, the representatives of different economic or social levels can come up against each other in lawsuits like those brought by citizens against corporations. This offers a way for relatively powerless individuals to try to make their case in national or international climate policy. This could play a vital role in the mitigation of climate change in light of the fact that worldwide, land is still_-increasingly_-falling into the hands of private 'climate-damaging' companies and landowners. If liability for climate damage attributable to companies were to be further enforced in court, this could create an economic incentive for them to reduce greenhouse gas emissions (GHGs). ${ }^{6}$ Finally, tort law could contribute with a multi-scale, multi-level response to the complex problem of climate change, with plaintiffs bringing their individual, various cases before the courts.

Thus, at first glance, everything appears to speak in favor of an efficient interaction between climate change and tort law to create a better legal framework for tackling climate change. Nevertheless, claims under tort law are — if at all—only very hesitantly brought before the courts. As indicated above, the answer to this appears to lie in the current 'inadequacies' of tort law and in the application of tort law before the courts in regard to climate change. Although courts have acknowledged that climate change is a major concern, the outcomes before the courts are sobering. ${ }^{7}$ This is because there are challenges at every step of the way, from identifying claimant and defendant to identifying causal links between them. ${ }^{8}$ This Article also points out which of those steps could already be overcome by the jurisdiction and where the help of the legislator would be needed to counteract climate change in the interest of an effective and future-oriented legal system.

\section{B. Terms, Definitions, and Legal Basis}

The multifaceted theme of this Article is discussed widely and differently. Thus, in a first step to clarify the scope of this Article, terms, definitions, and legal bases shall be discussed.

\section{Climate Change}

Climate change, in the broadest sense, is the difference in the earth's global climate or in regional climates over time. In the context of this Article, climate change means the changes in the Earth's climate system due to human activities, which contribute to global warming. The most

\footnotetext{
${ }^{3}$ Maria Lee, The Intersection Between Environmental Law and Tort Law, in DECISION MAKING IN ENVIRONMENTAL Law 12 (LeRoy Paddock, Robert Glicksman \& Nicholas Bryner eds., 2016).

${ }^{4}$ Mark Latham, Victor E. Schwartz, \& Christopher E. Appel, The Intersection of Tort and Environmental Law: Where the Twains Should Meet and Depart, 80 Fordham L. Rev. 737, 739 (2011).

${ }^{5}$ Maria Lee, Climate Change Tort (Aug. 28, 2015) (unpublished paper) (on file with J. EnvT'L L.).

${ }^{6}$ Shi-Ling Hsu, A Realistic Evaluation of Climate Change Litigation through the Lens of a Hypothetical Lawsuit, 79 U. COLO. L. REv. 701, 717 (2008).

${ }^{7}$ Jin Fong Chua, Corporate Liability and Risk in Respect of Climate Change, N.Z. J. ENV’T L. 167, 184 (2016).

${ }^{8}$ Lee, supra note 3 , at 4 .
} 
influential human activity has been the emission of Green House Gases (GHGs) through fossil fuel burning. In addition, agricultural emissions and deforestation also play significant roles. ${ }^{9}$ These emissions lead to shifting patterns that threaten food production and rising sea levels that increase the risk of catastrophic flooding. Therefore, the impacts of climate change are global in scope and unprecedented in scale. ${ }^{10}$

Climate change is an extremely complex problem and many factors, interactions, and effects have not yet been proven with irrefutable certainty. Nevertheless, there is a strong body of evidence, based on multiple lines of research, documenting that the climate is changing. ${ }^{11}$ The International Panel on Climate Change (IPCC) has concluded that it is "very likely" that human activity is the cause. ${ }^{12}$ With regard to the effects of climate change, it can be said that while some phenomena such as sea-level rise cannot be explained without climate change, it is hardly possible to determine with certainty whether extreme weather events, such as storms or floods-like the recent flooding in western and central Europe or fires like the wildfires in the western United States of America-are attributable to climate change because such events can also occur under natural conditions. In some cases, however, the probability of causation can be determined, partly by using climate models and partly by using a statistical method. In each case, it was determined to what extent the probability of the occurrence of a concrete event with a specific intensity has increased due to climate change. ${ }^{13}$

\section{German Tort Law}

Based on a civil law legal system, German tort law is, in essence, codified in $\$ \$ 823-53$ Bürgerliches Gesetzbuch (BGB, the Civil Code). But also outside these norms, there are tort provisions-for example, $\$ \$ 1$ and 2 Umwelthaftungsgesetz (UmwHG, the Environmental Liability Act). ${ }^{14}$ Thus unlike, for example, its French-Article 1382 French Civil Code-or Austrian-\$ 1295(1) Austrian Civil Code-predecessors, the BGB does not contain a general tort provision, which imposes tortious liability for simply any harmful human conduct. ${ }^{15}$ Instead, it offers a comprehensive catalog of provisions, which follow the, rather strict, structure prescribed by the law. With a few exceptions, fault is regarded as the general rule of liability. This is also expressed in $\$ 823$ BGB, German law’s basic tort provision. A specific provision concerning climate change or environmental liability does not exist.

This Article focuses exclusively on those tort provisions that can be applied in private litigations, leaving out state liability. This is because private companies and private landowners have, by far, the biggest impact on the environment and climate. ${ }^{16}$ Also, state liability mostly takes place in public law and not in tort law. Norms of state liability law, such as $\$ 839$ BGB, Article 34 of the Grundgesetz (GG, the German Constitution), therefore, only play a role if the conditions do not differ and approaches can be transferred to private law matters. ${ }^{17}$

\footnotetext{
${ }^{9}$ U.S. Environmental Protection Agency, Global Greenhouse Gas Emissions Data, United StATES GovernmENT, https:// www.epa.gov/ghgemissions/global-greenhouse-gas-emissions-data.

${ }^{10}$ United Nations, Climate Change, https://www.un.org/en/global-issues/climate-change.

${ }^{11}$ Nat'l Research Council, America's Climate Choices: Panel on Advancing the Science of Climate Change 1, 21-22 (2010).

${ }^{12}$ Richard P. Allan et al., Climate Change 2021. The Physical Science Basis, Intergovernmental Panel On Climate CHANGE (2021), https://www.ipcc.ch/report/ar6/wg1/downloads/report/IPCC_AR6_WGI_Full_Report.pdf.

${ }^{13}$ Erik PÖtTKer, Klimahaftungsrecht 17 (2014).

${ }^{14}$ Otto Palandt, Bürgerliches Gesetzbuch mit Nebengesetzen $\$ 823$, at 7, 11 (Brudermüller, Ellenberger, Götz, Grüneberg, Hernler, Spra, Thorn, Weidenkaff, Weidlich \& Wicke eds., 79th ed. 2019).

${ }^{15}$ Heinz Georg Bamberger et al., Beck Online Kommentar $\$ 823$, at 2 (Wolfgang Hau et. al. eds., 54th ed. 2020).

${ }^{16}$ Germany CO2 Emissions, WORLDOMETER, https://www.worldometers.info/co2-emissions/germany-co2-emissions/ (last visited Oct. 14, 2021).

${ }^{17}$ In this context, state liability cases of civil law legal systems, such as Hof s-Gravenhage 9 oktober 2018, AB 2018, 417 m.nt. GA van der Veen, Ch.W. Backes (Staat der Nederlanden/Urgenda) (Neth.), https://www.urgenda.nl/wp-content/uploads/ ECLI_NL_GHDHA_2018_2610.pdf, [hereinafter State of the Netherlands v. Urgenda Foundation], will also play a role.
} 
In this context, defendants are mainly companies emitting GHGs. Companies are to be understood here as subjects of private law that, irrespective of the form of their organization, are not consumers but entrepreneurs-meaning that they are commercially driven. It should also be noted that companies cannot act themselves but act through their executive bodies. German company law has a number of vicarious liability provisions, such as the basic liability of executive bodies under $₫ 31 \mathrm{BGB}$, which is applicable mutatis mutandis to various types of companies. ${ }^{18}$ Insofar as the claims to be examined in the following Article require corresponding action on the part of the defendant, or are directed at certain conduct, the attribution of the executive body action is presupposed and, for the sake of simplicity, only the action of the defendant is spoken of. The same applies, as far as claims require subjective characteristics, in particular fault.

\section{German Climate Change Law}

Article 20a GG enshrines the "protection of the natural foundations of life" as a state task which, according to a prevailing opinion, also includes the protection of the climate and the protection of natural foundations of life against climate change. ${ }^{19}$ It is binding on the legislator but is not an enforceable fundamental right. At the federal level, the Federal Climate Protection Act 2019-now revised after the ruling of the Bundesverfassungsgericht-plays the decisive role in public climate change law. It is designed to ensure that national climate protection targets are met and that European targets are adhered to. With the Climate Protection Act, the climate targets for 2030 are legally standardized. It is based on the obligation under the Paris Climate Agreement, according to which the rise in the global average temperature must be limited to well below $2^{\circ} \mathrm{C}$ and, if possible, to $1.5^{\circ} \mathrm{C}$ compared with pre-industrial levels in order to keep the effects of global climate change as low as possible. This is also on track with Germany's commitment to pursuing GHG neutrality by 2050 . Furthermore, isolated climate change laws exist at state level. All laws are public laws and also lack enforceability. Because German climate change and environmental law are not uniform fields of law, administrative and civil law provisions are applicable on a case-by-case basis. ${ }^{20}$ The extent to which this affects tort law will be discussed below.

\section{Climate Litigation}

Climate change litigation, in the broadest sense, is concerned with disputes over laws, acts, or omissions relating to climate change mitigation and adaptation measures. Such lawsuits are becoming increasingly popular, especially in the U.S. and Australia, ${ }^{21}$ where the term climate litigation has been established, primarily in relation to the common law system. In Germany —additionally to the English term climate litigation - the German equivalent 'Klimaklage' is used, which has the same meaning. It is also to be expected that the number of climate litigations in Germany will increase due to the presence of international organizations in Germany, such as the non-profit organization, Client Earth, which is taking legal action against governments and corporations that are fueling climate change. The parties to these suits may be citizens, businesses, NGOs, and local, state, or federal governments or other state organizations. Disputes may be brought before regional, national, or international courts. ${ }^{22}$ The term climate litigation in this Article covers - in line with the above-only tort litigation and, in this context, merely litigation between private parties, instead of the state. Defendants are, therefore, mostly private companies.

\footnotetext{
${ }^{18}$ PALANDT, supra note 14 , at $\$ 31,3$.

${ }^{19}$ See Michael Sachs, Grundrechte: Klimawandel, 7 JuS 708 (2021).

${ }^{20}$ Rolf Schwartmann \& HeinZ-Joachim Pabst, Umweltrecht 202 (2d ed. 2011).

${ }^{21}$ Jacqueline Peel \& Hari M. Osofsky, Climate Change Litigation: Regulatory Pathways to Cleaner Energy 1-27 (2015).

${ }^{22}$ David Markell \& J.B. Ruhl, An Empirical Assessment of Climate Change in the Courts: A New Jurisprudence or Business as Usual?, 64 Fla. L. REV. 15, 27 (2012).
} 


\section{Climate Change and the German Law of Torts}

In the following, the various tort provisions - in essence, these are the above-mentioned provisions of $\$ 823 \mathrm{BGB}$ and $\$ \$ 1$ and $2 \mathrm{UmwHG}$ - and their problematic prerequisites, as well as legal remedies in the light of climate change, shall be discussed. Where possible, the case, Lliuya $v$. RWE AG, shall serve as a model. On the facts of this case: ${ }^{23}$ In 2015, a Peruvian farmer sued the German energy company, RWE, to pay a share of 17,000 Euros of his adaptation costs, which he was incurring because of the climate change caused by RWE. The resulting melting of the glaciers had caused the water level of the glacial lake Palcacocha in the Peruvian Andes to rise to a level, threatening to wash away his house below the lake, by a glacial run. According to the plaintiff, RWE is responsible for $0.47 \%$ of climate change-which corresponds to its share of global GHG emissions-and thus also for the state of the glacier lake. The action was dismissed at first instance by the Landgericht Essen (LG Essen, Regional Court of Essen). An appeal was lodged against this judgment. At the end of November 2017, the Oberlandesgericht Hamm (OLG Hamm, Higher Regional Court of Hamm), as the appellate court, decided to admit the evidence. Thereafter, a decision of evidence was made which should soon result in a judicial inspection in Peru. A decision is still pending.

\section{I. $\S 823$ (1) BGB}

The basic tort provision expressed in $₫ 823$ BGB —-whereby subsections 1 and 2 constitute two different types of liability—will be dealt with first. $\$ 823$ (1) BGB states that a person who, intentionally or negligently, unlawfully injures the life, body, health, freedom, property, or another right of another person is liable to make compensation to the other party for the damage arising from this.

\section{Violation of Protected Rights and Interests}

$\$ 823$ (1) BGB contains a restriction to certain legal rights and interests, like the right to life, body, health, freedom, property, or another right. For climate change, the violation of property is of primary importance. Such a violation only occurs if the material substance is damaged or destroyed, or if the possibility of use is restricted due to an impairment. ${ }^{24}$ Property here means private property; however, there is no ownership or possession of the climate. Also, the violation of other rights, such as health or "another right" — which must also be an absolute right like life, body, health, freedom, or property - can play a role. ${ }^{25}$ Thus, a violation of these rights can be seen, for instance, in climate change caused by GHG emitters, leading to global warming and thus to droughts that affect property, possession, and/or health. Problematic in this context is that, according to the current opinion in jurisprudence, the list of legal interests that can be violated shows that $\$ 823$ (1) BGB does not cover pure financial losses. ${ }^{26}$ This is in contrast to the tort of negligence under common law, which is based on the British legal system. Thus, it does not cover, for example, loss of turnover or mis-investment. The courts justify this through the legal concept of $\$ \$ 844$ and 845 BGB and, more importantly, the otherwise obvious proliferation of liability if the number of potential claimants is not limited from the outset. ${ }^{27}$ This very justification leads to a narrow and restrictive interpretation of the law and raises the fundamental question of whether the issue of climate change-possibly leading to an unlimited number of potentially affected parties and thus entitled persons-should be solved with tort law at all. This issue, however, was not considered in Lliuya v. RWE AG.

\footnotetext{
${ }^{23}$ Landgericht [LG] [Regional Court] Essen, Dec. 15, 2016, 2 O 285/15, at para. 4, https://openjur.de/u/943890.html, [hereinafter Lliuya v. RWE AG].

${ }^{24}$ PALANDT, supra note 14 , at 202.

${ }^{25} I d$. at $202-03$.

${ }^{26}$ BAMBERGER ET AL., supra note 15 , at $\$ 823,3$.

${ }^{27}$ See, e.g., Bundesgerichtshof [BGH] [Federal Court of Justice] Aug. 28, 2003, 14 Neue JuristisCHE WoCHENSCHRIFT [NJW] 1040, at 1041 .
} 
It is arguably the courts' discretion to soften this strict interpretation of the law in climate litigation. For a more "climate-friendly" interpretation of the law, it may well be doubted whether such a narrow interpretation is correct at all because reactive German tort law is, amongst other things, intended to compensate for damages in so far as they have occurred, irrespective of any higher economic or political considerations. If courts stick to a strict interpretation and thus interpret, in general, $₫ 823$ (1) BGB in the way described above, exceptions to the jurisprudence concerning climate change could be introduced. Thus, there would be ways and means to circumvent this problem —in favor of climate plaintiffs—created by the jurisdiction itself.

\section{Infringement Act}

The violation of rights and interests must be the result of an act of infringement, which leads to another, albeit minor, problem in the context of climate change. An infringing act is a human behavior - which is subject to control by consciousness and will- that is, in this respect, fundamentally controllable, and which can consist of either an action or an omission. ${ }^{28}$ It could be argued that climate change occurs as a result of actively emitting GHGs into the atmosphere. However, if, for example, the owner of a GHG emitting company fails to observe certain standards, the behavior must rather be considered as an omission to comply with those standards. In this case, a violation of the socalled property owner's, manufacturer's, etc. "Verkehrssicherungspflicht" or "Verkehrspflicht" (duty of care) comes into consideration. In Germany, a "Verkehrssicherungspflicht" is a tort law obligation to act in order to avert sources of danger; the failure to do so leads to claims for damages. This obligation arose against the background of the "unlawful violation" of the protected rights and interests, mentioned in $\$ 823(1)$ BGB. This duty mainly consists of making sure that dangers arising from an opened hazard source do not materialize. ${ }^{29}$ In any case, the existence of such a duty towards everyone is highly debated. ${ }^{30}$ Again, the argument of proliferation of liability plays a role in this discussion. ${ }^{31}$ Thus, the key, again, lies in the interpretation of the courts.

In the Dutch civil law case State of the Netherlands v. Urgenda Foundation, the Court of The Hague affirmed a duty of care of the state towards its citizens against climate changes that endanger life and health, which result from state liability law. ${ }^{32}$ If private companies-especially large, private companies-act like states in scope and behavior, this decision could be applied accordingly. The comparison of large companies to the state has not yet been discussed in the Netherlands, where, for example, RWE AG is also one of the leading energy suppliers. It is no different in Germany. The example of the pan-European group of the RWE AG shows the economic size and power of such climate-damaging companies. From the standpoint of economic power, at least, equal treatment with a state power would be justified and, thus, the attribution of a duty of care to be observed.

\section{Causation}

Causation is arguably the biggest and most debated problem in climate litigation and will continue to be one of the most crucial issues that courts will have to deal with in the future. ${ }^{33}$ As in common law jurisdictions, German civil law applies a two-fold test for causation. A distinction is made between the question of causal relationship in the logical or scientific sense between the action and the loss - in other words, causation - and the further question of whether it is justified to hold the person who has caused the loss responsible-in other words, accountability. As in

\footnotetext{
${ }^{28}$ Franz JÜrgen Säcker, Roland Rixecker, Hartmut Oetker \& Bettina Limperg, Münchener Kommentar zum BÜrgerlichen GesetzBUCH: BGB $\$ 823$, at 63 (Franz Jürgen Säcker, Roland Rixecker, Hartmut Oetker \& Bettina Limperg eds., 7th ed. 2017).

${ }^{29}$ BAMBERGER et al., supra note 15 , at $\$ 823,74$.

${ }^{30}$ PALANDT, supra note 14 , at $\$ 823,51$.

${ }^{31}$ See supra Section C.I.1.

${ }^{32}$ State of the Netherlands v. Urgenda Foundation at para. 43.

${ }^{33}$ Will Frank, Klimahaftung und Kausalität, ZeITSCHRIFT FÜR UMWELTRECHT 28, 28-29 (2013).
} 
German law, causation - a scientific and not legal term ${ }^{34}$-in the logical or scientific sense is judged according to the conditio-sine-qua-non formula, which corresponds to the "but for test" in the common law. According to this test, an event is to be viewed as a cause if, without it, the result, in its specific form, would not occur. In terms of climate change, the question would, therefore, be: Would a specific event or change occur without the emission of a specific company's or individual's GHGs? ${ }^{35}$ This view, which is based on a probability analysis, needs to be supplemented by an evaluative assessment-accountability. Accountability is, therefore, a normative evaluation which is additionally applied.

In Lliuya v. RWE AG, at first instance, the LG Essen dealt in depth with the question of causation and denied it mainly for two reasons. First, according to the court, the complexity of climate change and its consequences would make it impossible to trace a clear causal link between the emissions of the defendant's power plants and the endangerment of the plaintiff s house in Peru. ${ }^{36}$ Secondly, the court held further that it is not justified to hold the defendant responsible because of the countless other contributors to climate change. ${ }^{37}$ Therefore, the defendant is not accountable. To emphasize the causal link, on his appeal, the plaintiff argues that the whole causal chain can be traced along the following steps: The released emissions of the defendant end up in the atmosphere, where they lead to an increased concentration of GHGs in the entirety of the Earth's atmosphere. Due to the increased density of GHGs in the atmosphere, heat dissipation from Earth and, thus, global temperatures are increased. The rise of global temperatures leads to the accelerated meltdown of glacierslike the one near the plaintiff s house-and heightens the probability of glacial break-offs. Due to the accelerated glacial meltdown, the water volume in lake Palcacocha increases, which, in turn, increases the threat of the plaintiff s property falling victim to a possible flood wave.

The OLG Hamm has now, at second instance, recognized the evidence-rightly so-and entered into a lengthy hearing. ${ }^{38}$ Fundamentally, it follows the highest German courts, which have implicitly already accepted that anthropogenic climate change exists. ${ }^{39}$ It also seems to follow the plaintiff's arguments. According to these arguments, the specific event or change would not occur without anthropogenic emissions. The causal link presented by the plaintiff reflects the current state of research, is logically comprehensible, ${ }^{40}$ and complies with the international standards of the IPCC. ${ }^{41}$ Some scholars have criticized that climate models—-such as those of the IPCC-are not sufficient as evidence, as they only show a statistical probability. ${ }^{42}$ However, the probability that speaks against anthropogenic climate change is negligible. ${ }^{43}$ Rather, it is not obvious why climate models should not be considered as evidence. In particular, climate reports and models help measure the contributions of different emitting sources-which also helps in understanding other factors that might endanger causation, such as already existing GHGs that could have been released from a variety of sources like volcanic eruptions, decaying biomass, or animal respiration. If a specific causal contribution to climate change can be determined-as is the case with the large company RWE - then this is a very sound argument in favor of causation. Following this, increasingly more scholars support the application of international or national reports on climate change

\footnotetext{
${ }^{34}$ Roda Verheyen, Loss and Damage Due to Climate Change: Attribution and Causation-Where Climate Science and Law Meet, 8 InT'L J. Glob. WARMING 158, 161 (2015).

${ }^{35} \mathrm{Id}$. at 163 .

${ }^{36}$ Lliuya v. RWE $A G$ at para. 44.

${ }^{37} I d$. at 43.

${ }^{38}$ Landgericht [LG] [Regional Court] Essen, Nov. 30, 2017, 2 O 285/15, [hereinafter Decision of Evidence].

${ }^{39}$ See, e.g., Bundesverwaltungsgericht [BVerwG] [Federal Administrative Court] Jan. 25, 2006, Case No. 8 C 13/05, https:// www.bverwg.de/250106U8C13.05.0; Bundesverfassungsgericht [BVerfG] [Federal Constitutional Court] Mar. 13, 2007, 1 BvF 1/05, https://www.bundesverfassungsgericht.de/SharedDocs/Entscheidungen/DE/2007/03/fs20070313_1bvf000105.html.

${ }^{40}$ David Grossman, Warming Up to a Not-So-Radical Idea: Tort-Based Climate Change Litigation, 28 Colum. J. ENV'T L. 1 , 27 (2003).

${ }^{41}$ See supra Section B.I.

${ }^{42}$ Alexandros Chatzinerantzis \& Markus Appel, Haftung für Klimawandel, 13 NJW 881, 883 (2019).

${ }^{43}$ See supra Section B.I.
} 
in courts, especially like the one from the IPCC. ${ }^{44}$ In State of the Netherlands $v$. Urgenda Foundation, the court also relies heavily on IPCC reports and their acknowledgment by others, including the United Nations Framework Convention on Climate Change (IPCCC) and their Conferences of Parties (COPs). That the court rejected causation in State of the Netherlands $v$. Urgenda Foundation in the end was mainly because the plaintiff claimed for an order and not for damages. ${ }^{45}$ Thus, causation played a limited role in this case.

Arguably, courts like the LG Essen would be even more hesitant if extreme weather events-for example, storms or floods-were the reason for climate litigation. As mentioned in Part B.I of this Article, it is, in fact, still difficult to prove a relationship on a case-by-case basis between climate change and the respective event, particularly under the strict criteria for causation of the conditio-sine-qua-non rule. ${ }^{46}$ By legal standards, a mere statistical correlation may not be regarded as sufficient proof of causation. ${ }^{47}$ Nevertheless, since about the middle of the 2010s, so-called attribution science has also gained importance in climate research, investigating the contribution of climate change to individual extreme weather events. Lawyers and scholars expect that, with the increasing understanding of what weather events can be expected, the responsibilities and liability of states and non-state actors will change. ${ }^{48}$

Regarding the second issue of accountability and the reason why the LG Essen rejected it, it is true that the extraordinary number of GHG emitters leads to implications for establishing causation, as any individual defendant can quite plausibly offer the "consequentialist alibi" that its emissions are simply too small of a share among global emissions to cause a discernible difference. ${ }^{49}$ This is also related to the issue denounced by many, and already indicated above, that actions of one emitter are arguably almost never the direct cause, and a potential plaintiff would only be able to show that the defendant-company's actions increased the risk of causing damage $\mathrm{e}^{50}$ because one never knows where the exact harming pollution comes from. ${ }^{51}$ In the case of the large company RWE, however, the above-mentioned scientific, logical, and legal arguments arguably already speak against this argument. Additionally, the multitude of emitters or co-causersaccording to many - is not a convincing reason for a "blanket ban" on legally attributing liability for causal contributions by individual emitters that are quantifiable and not insignificant. There is no legal basis for conflating the liability of major emitters for consequences of climate change, for which they are, to a significant extent, co-responsible with a de facto "collective non-responsibility" of the countless minor emitters. ${ }^{52}$ According to so-called cumulative causation, the act of an offender is still a cause even if it, in and of itself, could not result in the damage but only in combination with the actions of another. ${ }^{53}$ Arguably, in this context, the OLG Hamm has already indicated that it could decide the issue of causation differently from the LG Essen.

Moreover, $\$ \$ 830$ and 840 BGB arguably have no bearing on the context of climate change. $\$$ 830 BGB regulates the liability of joint tortfeasors and participants - in other words, persons involved together; companies emitting GHGs, however, do not act as such but rather independently of each other, side by side as secondary offenders. Section 830(1) sentence (1) and (2) BGB

\footnotetext{
${ }^{44}$ Maria Lee, The Sources and Challenges of Norm Generation in Tort Law, EUR. J. RisK REG. 1, 9 (2018); Kysar, supra note 1, at 4.

${ }^{45}$ State of the Netherlands v. Urgenda Foundation at para. 2.18.

${ }^{46}$ See supra Section B.I.

${ }^{47}$ Will Frank, Störereigenschaft für Klimaschäden - Anmerkungen zum Urteil des LG Essen vom 15.12.2016 in der ersten deutschen Klimaklage, NVwZ 6 (2017).

${ }^{48}$ See, e.g., Sophie Marjanac \& Lindene Patton, Extreme Weather Event Attribution Science and Climate Change Litigation: An Essential Step in the Causal Chain?, 36 J. ENERGy NAT. Res. L. (2018).

${ }^{49}$ Kysar, supra note 1 , at 35.

${ }^{50}$ Chatzinerantzis \& Appel, supra note 42 , at 883.

${ }^{51}$ Donald Dewees, The Role of Tort Law in Controlling Environmental Pollution, 18 CAN. PuBliC POL. 425, 429 (1992); JOHN Lowry \& Rod Edmunds, Environmental Protection and the Common LaW 77, 83 (2000).

${ }^{52}$ Frank, supra note 47 , at 3.

${ }^{53}$ Verheyen, supra note 34 , at 163.
} 
cover complicity and participation in the criminal law sense, that means deliberate and intentional cooperation. In contrast, secondary offenders act independently of each other. They are only connected with each other through the subsequent damage. To be more precise, secondary offenders are deemed to exist if several independent perpetrators of an offense cause uniform damage without conscious cooperation. Section 840 BGB, in contrast, only covers joint and several liability as a legal consequence and is, therefore, not applicable when establishing the grounds for causation.

Finally, concerning causation as such, carbon budgets must be mentioned. The carbon budget is defined by the IPCC as the estimated amount of carbon dioxide the world can emit while still having a likely chance of limiting global temperature rise to $2^{\circ} \mathrm{C}$ above preindustrial levels. ${ }^{54}$ Carbon budgets are now also adopted in German law ${ }^{55}$ and-as set permissible annual emission quantities - have been said to provide a convenient tool for framing climate change litigation to establish a causal link and counter arguments that individual emissions are de minimus or vanishingly small. With an accurate measuring of the GHG emissions of individual private climate-damaging companies and landowners, it would be possible, in the future, to track exactly by how much the annual permissible emission quantities have been exceeded, thereby determining an exact liability share. In this respect, German climate legislation is quite progressive, considering that the so-called emissions budgets - the equivalent of permissible annual emission quantities-of countries such as the United Kingdom or New Zealand are set at four years.

Ultimately, we may see legal developments where novel concepts of causation come to the fore. One possibility is the probabilistic causation test, where even less than $50 \%$ contribution to the risk of harm suffices when the scientific evidence confirms the cause of damage. ${ }^{56}$ Worth mentioning is the Chinese courts' approach, applying the principle of causation presumption in environmental tort litigation, whereby the party causing the injury bears the burden of proving that there is no causation. ${ }^{57}$ In this respect, it is up to the courts to establish new standards of causation.

In any case, it is a fact that German tort law also-like in the common law system-in principle presumes that where two or more causes combine to bring about harm, an act is legally causative if it materially contributes to the harm. This causation is basically and factually given if the climatedamaging behavior of one company causes damage to someone else. If courts were to proceed on the basis of this principle, it would arguably be easier-in terms of the outcome-to circumvent any minor problems that might arise in relation to causation either by simplifying the normative requirements or by simplifying the requirements of evidence.

\section{Unlawfulness and Fault}

In German tort law, the violation of a certain protected right usually indicates unlawfulness. In climate litigation, however, it is questionable what effect it has if a company acts according to the law-some examples are: $\$ \$ 5,22 \mathrm{BImSchG}$ and the TA-Luft (technical instructions air) that set the allowed emission limits-or an official permit. In Lliuya $v$. RWE $A G$, according to the defendant's statement he complied with the legal and permit requirements. Because the LG Essen-already_ruled out causation ${ }^{58}$, it had not taken a position on this matter. This issue is similar to that of "statutory defense," discussed in the context of the common law. A reasonable climate-friendly way out of this problem is difficult to justify, legally. For this reason, the arguments in favor of illegality or against a statutory defense are usually political—and not very convincing legally.

\footnotetext{
${ }^{54}$ Kysar, supra note 1 , at 4 .

${ }^{55}$ See Bundes-Klimaschutzgesetz [KSG] [Federal Climate Protection Act], Dec. 12, 2019, BundesGesetZBlatt, Teil I [BGBL I] at $\$ 4$ (Ger.).

${ }^{56}$ Luke Elborough, International Climate Change Litigation: Limitations and Possibilities for International Adjudication and Arbitration in Addressing the Challenge of Climate Change, N.Z. J. ENVT'L L. 89, 99 (2017).

${ }^{57}$ Robert Blomquist, Comparative Climate Change Torts, 46 VAL. U. L. REV. 1053, 1065-66, 1074 (2012).

${ }^{58}$ See supra Section C.I.3.
} 
Furthermore, this creates an issue for fault, because fault must be denied if the defendant assumes that he acts within the framework of the law. ${ }^{59}$ The regulatory system of $₫ 823$ BGB per se cannot remedy this - in contrast to the UmwHG. ${ }^{60}$ It is discussed that defendants who have complied with the legal framework but are alleged to have been negligent nonetheless, must also be considered. Here, "climate-friendly" scholars would also argue-more politically and less legally convincing - that if compliance would provide an automatic defense, it would be impossible to use tort law to challenge climate change law. Nevertheless, it is not difficult to find cases in which a reasonable person is expected to do more than merely comply with regulations. ${ }^{61}$ In British common law, in confirming the reasonableness of relying on the Code of Practice, Lord Dyson, in Baker v. Quantum Clothing Group Limited, reminds us that regulatory instruments may be "comprised;" for example, in a failure to keep pace with changing technology and science. ${ }^{62}$

Under the German civil law's recently established climate budgets system, ${ }^{63}$ the assumption of an unlawful and negligent act is quite problematic if a company's emissions comply with both international and national climate budgets. Unlawfulness and fault, therefore, represent hurdles that are difficult to overcome for courts in climate litigation in Germany. In this respect, the courts are bound by the written and established law and cannot overrule the law. Therefore, even if one overcomes the above-mentioned problems of establishing causation or an infringement act, there are limits to the German civil law legal system, in which jurisprudence acts as a mere applicator and not as a creator of the law. Thus, the German legislator must create appropriate rules to allow for liability-as per $₫ 823$ BGB. Nevertheless, whether the German Parliament intervenes in the traditional and differentiated liability system of $\$ 823$ BGB by creating exceptions in the interest of tackling climate change seems questionable. From a legal policy perspective, the establishment of a specific, particular regulatory system for liability that is tailored to the problem of climate change appears to be more likely. ${ }^{64}$

\section{II. $\S 823(2) B G B$}

Following $\$ 823(1)$ BGB, subsection 2 states that the same duty-as in subsection 1 -is held by a person who commits a breach of a statute that is intended to protect another person. The most important difference between subsection 1 and 2 consists of extending the scope of protection of general tort liability to pure financial losses. ${ }^{65}$ The specific prerequisite of $₫ 823(2)$ BGB is a breach of a protective statute. A protective statute, in this sense, is not every statute, but only one that aims precisely at protecting the claimant. Currently, the only statutes that are intended to protect the climate are public laws_-such as the Bundes-Klimaschutzgesetz-and, thus, do not aim precisely at protecting the claimant but the climate as such. Different reasoning is difficult to justify under the current German legal situation ${ }^{66}$. Furthermore, the problems of causation, and especially of unlawfulness, and fault ${ }^{67}$ also exist in the context of $\$ 823(2)$ BGB.

\section{Strict Liability}

Furthermore, there are regulations on strict liability, which will be discussed in the context of the climate litigations.

\footnotetext{
${ }^{59}$ Wissenschaftliche Dienste des Deutschen Bundestags, Rechtliche Grundlagen und Möglichkeiten für Klima-Klagen gegen Staat und Unternehmen in Deutschland, Deutscher Bundestag 10-11 (2016).

${ }^{60}$ See infra Section B.III.

${ }^{61}$ Lee, supra note 3 , at 9 .

${ }^{62}$ Baker v. Quantum Clothing Group Limited [2011] UKSC 17 (appeal taken from EWCA) (U.K.) https://www. supremecourt.uk/cases/docs/uksc-2009-0108-judgment.pdf.

${ }^{63}$ See supra Section B.III.

${ }^{64}$ See infra Section C.III.1; supra Section B.II.

${ }^{65}$ SäCKER et al., supra note 28 , at $\$ 823,540$.

${ }^{66}$ See supra Section B.II.

${ }^{67}$ See supra Section C.I.3, 4.
} 


\section{Sections 1 and 2 UMWHG}

If liability fails due to a lack of fault, provisions of strict liability can be considered. In this context, the UmwHG, in particular $\$ \$ 1$ and 2 UmwHG, should be considered. These provisions state the following liability: If an environmental impact, caused by a facility or a facility that is not yet completed, causes a person's death, injury to his body or damage to his health or property, the operator of the facility shall have an obligation to compensate the injured person for the resulting damage. The term facility includes several GHG emitting companies-like combustion installations for the use of coal and oil. According to these provisions, for the plaintiff, the UmwHG therefore also has the advantage that - in contrast to general tort law-there is no need for the conduct to be unlawful. Therefore, emissions even within the scope of an official permit or within the legal framework, would also be covered ${ }^{68}$ Furthermore, in terms of causation, $\$ 6$ UmwHG states that, if a facility is likely to cause the damage that occurred on the basis of the given facts of the individual case, it is presumed that the damage was caused by this facility. The UmwHG, therefore, appears to be quite promising from a plaintiffs perspective. Nevertheless, there has not yet been a case in practice based on these provisions, which is arguably due to the following reasons: A claim based on $\$ \$ 1$ and 2 UmwHG is limited in terms of compensation. ${ }^{69}$ Moreover, most "extreme weather events" are excluded by $\$ 4$ UmwHG, stating that no liability for damages shall exist insofar as the damage was caused by force majeure. In addition, only the environmental impacts caused by certain companies are covered-see the definition of the term facility. Finally, and most importantly, it is not possible to determine in general whether the UmwHG is eligible for climate litigation, as it only covers damage caused by environmental impacts within the meaning of $\$ 3$ UmwHG. ${ }^{70}$

Therefore, the UmwHG has quite useful approaches in favor of plaintiffs that would circumvent the issues which arose in relation to $\$ 823(1)$ and (2) BGB — for instance and especially causation, unlawfulness and fault. Nevertheless, the UmwHG is not tailored to the case of climate change, which can be seen in the issue of determining whether the UmwHG is eligible for climate litigations at all. As a regulatory framework for liability, however, the UmwHG could certainly serve as a role model for the legislator should he decide to take action against climate change. What such a system could look like is a question of its own, the discussion of which would go beyond the scope of this Article. But what is clear is that it must be in line with the recently established Bundes-Klimaschutzgesetz.

\section{Other Provisions on Strict Liability}

Other strict liability provisions could also have a factual link to climate change, such as $\$ 7$ Straßenverkehrsgesetz (StVG, the Road Traffic Act), which provides liability of a vehicle holder, $\$ 33$ Luftverkehrsgesetz (LuftVG, the Air Traffic Act), which provides liability in the case of an aircraft accident, or $\$ 833 \mathrm{BGB}$, which provides liability of an animal—such as GHG emitting cows—-keeper. These provisions, however, do not seem very promising in terms of climate litigation. For example, $\$ 7 \mathrm{StVG}$ is arguably not applicable because climate change does not happen "during the operation of a motor vehicle" and $\$ 33 \mathrm{LuftVG}$ is not applicable, as climate change is not an accident in the sense of this provision. Moreover, the GHGs of individual motor vehicles, aircrafts, or animals are too insignificant and, therefore, negligible. Finally, none of these provisions covers the case of climate change according to their purpose or their legal-historical intention.

\footnotetext{
${ }^{68}$ Alexandros Chatzinerantzis \& Benjamin Herz, Climate Change Litigation - Der Klimawandel im Spiegel des Haftungsrechts, NJOZ 594, 596 (2010).

${ }^{69} \mathrm{See}$ Umwelthaftungsgesetz [UMwHG] [Environmental Liability Act], Jul. 17, 2017, BundesGeSETZBLATt, TeIL I [BGBL I] at $\$ 15$ (Ger.).

${ }^{70}$ Wissenschaftliche Dienste des Deutschen Bundestags, supra note 59, at 11.
} 


\section{Legal Remedies}

As to compensable damage, German tort law adheres to the universal principle of restitutio in integrum as a "starting-point."71 The basic principle of full compensation for damage suffered is thus limited by the policy that tort law must not result in enrichment. ${ }^{72}$ Furthermore, only actual damage is compensable, meaning that "the damage must have been felt." ${ }^{\text {"3 }}$ The plaintiff must present evidence of the loss. ${ }^{74}$ Focusing on climate change context, depending on the objectives of statutes, compensation ability could differ, for example, compensation for the violation of a protected right by $₫ 823(1) \mathrm{BGB}^{75}$ In this context, a problem for plaintiffs, in the context of climate change, is that the most devastating impacts of GHGs are not expected to begin until later this century, and thereafter. ${ }^{76}$ And because plaintiffs under German law cannot seek recovery for a present risk of future harm, they can only file an action for acknowledgment on the grounds that the prerequisites of a tort provision exist. ${ }^{77}$ Nevertheless, there are no practical court decisions on this yet. Whether the courts will decide in favor of the plaintiffs in climate litigation is not unlikely, as the legal requirements for such an action for acknowledgment exist.

Furthermore, the BGB also contains claims for removal or injunction, in particular $\$ 1004(1)$ BGB and $\$ 862$ (1) BGB. According to $\$ 1004$ (1) BGB a property owner may require removal of interference if a disturber interferes with the ownership. If further interferences are to be feared, the owner may seek a prohibitory injunction. It is recognized by the courts that a claim based on $₫$ 1004(1) BGB can rest on a violation of every protected right and interest stated in $\$ 823(1)$ BGB - such as health. ${ }^{78}$ In Lliuya v. RWE AG, the plaintiff primarily based his claim on $\$ 1004(1)$ BGB since there was no actual damage-yet. The problem here is that the disturber mentioned in $\$$ 1004(1) BGB must be causal for the interference. Thus, the above-mentioned problem of causation also exists here. Accordingly, the LG Essen dismissed the action here- - with the above-mentioned statements on causation. ${ }^{79}$ For the current state of discussion, the current state of jurisdictional practice, and potential approaches to solving the problem of causation, the above comments can be referred to. ${ }^{80}$

Another issue comes with assessing the damage. In this respect, there are essentially no differences to common law. The ideas here are manifold. Some scholars suggest a system of proportionate liability, ${ }^{81}$ while others promote the market share theory when apportioning the responsibility of defendants in causal intractable drug liability cases. ${ }^{82}$ However, as regulators grapple with the challenge of compounding centuries-spanning climate impacts into the price of carbon, courts might feel less timid using the liability system to bridge two or three decades in the case of toxic substances exposure. ${ }^{83}$ Section 287(1) ZPO, titled "Investigation and Determination of Damages," speaks for the courts on this issue: "Should the issue of whether or not damages have occurred, and the amount of the damage or of the equivalent in money

\footnotetext{
${ }^{71}$ See Bürgerliches Gesetzbuch [BGB] [Civil Code], $\$ \$ 249-58$ (Ger.).

${ }^{72}$ Marie-Louise Larsson, The Law of Environmental Damage: Liability and Reparation 351 (1999).

${ }^{73}$ Bundesgerichtshof [BGH] [Federal Court of Justice] Nov. 22, 1985, NEUE JuRISTISCHE WochensCHRIFT [NJW] 2037 (1986) (Ger.).

${ }^{74}$ LARSSON, supra note 72 , at 351.

${ }^{75} \mathrm{Id}$. at 353. See also supra Sections B.II \& C.I.1.

${ }^{76} \mathrm{Kysar}$, supra note 1 , at 42.

${ }^{77}$ See Zivilprozessordnung [ZPO] [Code of Civil Procedure], $₫ 256(1)$ (Ger.).

${ }^{78}$ BAMBERGER et al., supra note 15 , at $\$ 823,50$.

${ }^{79}$ Lliuya v. RWE AG at para. 40-47. Another issue concerning $\$ 1004$ of the BGB is that interference must be tolerated if insignificant. See Bürgerliches Gesetzbuch [BGB] [Civil Code], $\$ 906$ (Ger.). This is arguably the case for minor emitters. See Pöttker, supra note 13, at 127; supra Section C.I.3.

${ }^{80}$ See supra Section C.I.3.

${ }^{81}$ L.C. Chambers, Tort Law, Climate Change and Private Nuisance 35 (2012).

${ }^{82}$ Climate Change Liability: Transnational Law and Practice 5.83 (Richard Lord, Silke Goldberg, Lavanya Rajamani \& Jutta Brunnée eds., 2012).

${ }^{83} \mathrm{Kysar}$, supra note 1 , at 71 .
} 
to be reimbursed, be in dispute among the parties, the court shall rule on this issue at its discretion and conviction, based on its evaluation of all circumstances."

\section{Conclusion}

In broad summary, it can be said that the German tort law has minor to major obstacles of various kinds in regard to climate change. Causation seems to be the "holy grail" of climate litigation and a central issue that future litigation will grapple with. But, even this major issue does not seem to be insurmountable, bearing in mind the general principle that where two or more causes combine to bring about harm, an act is legally causative if it materially contributes to the harm. ${ }^{84}$ And - arguably most importantly_headway being made in science, including developments in climate science and research-particularly attribution science-will bolster the prospect of success in climate litigation. Courts may be more willing to hold corporations responsible if emissions can be scientifically linked to actions. ${ }^{85}$

But, also, other prerequisites of tort law like unlawfulness and fault represent hurdles that are difficult to overcome for courts in climate litigation in Germany. Whether these hurdles can be circumvented seems highly questionable. At least the classic tort law provisions—such as $\$ 823(1)$ and (2) BGB - do not appear to be a sufficient legal foundation for plaintiffs in climate litigation.

Nevertheless, this Article also clearly demonstrates that the issues, arising in the area of climate change and tort law, are not very different from those of the common law systems. Causation is also a major issue in climate litigation in common law and the type of violation or its consequences, as well as statutory defenses-comparable to the issue of unlawfulness explained above, ${ }^{86}$ also play a major role there. The difference between the civil law and the common law system arguably is that the latter is said to be more flexible and, therefore, more easily and quickly adjustable. Many scholars, particularly Douglas A. Kysar, believe that the common law tort system has all the tools to include the issue of climate change in the tort structure. ${ }^{87}$ And although it is true that in the German civil law legal system, the constituent elements of a tort provision can be interpreted more "climate-friendly" and thus become more flexible, German courts, in particular, seem to be cautious when it comes to wide interpretation. In general, courts ensure that statutory interpretation does not cross the boundaries of the statutory wording. It is, therefore, not surprising that in German jurisprudence a change in the law towards a new regulatory private law climate change system is seen as the only solution to tackle climate change with tort law. That such a system must be introduced in the near future is mainly supported by the fact that the German state, in particular, has a legal duty to provide negotiated solutions where environmental damage is expected to occur so that prompt and adequate compensation can be obtained in practice. ${ }^{88}$ This view is supported by the International Law Institute, many lawyers, and other scholars. ${ }^{89}$ In this context, as shown above, ${ }^{90}$ an implementation, following the example of the UmwHG, could be a conceivable solution. Following the example of the UmwHG, this could at least lead to a looser definition of the elements of a tort provision or abolishment of the prerequisite of unlawfulness, which would cover emissions even within the scope of an official permit or within legal limits. Furthermore, the requirements of either proving causation or determining the degree of causation could be redefined in favor of climate litigants. Therefore, the UmwHG could certainly serve as a role model for the legislator.

\footnotetext{
${ }^{84}$ Saul Holt \& Chris McGrath, Climate Change: Is the Common Law up for the Task, 24 AUCKLAND U. L. REV. 24, 28 (2018).

${ }^{85}$ Kysar, supra note 1 , at 4 .

${ }^{86}$ See supra Section C.I.4.

${ }^{87}$ Kysar, supra note 1.

${ }^{88}$ See, e.g., Grundgesetz [GG] [Basic Law], art. 20a (Ger.).

${ }^{89}$ Verheyen, supra note 34 , at 16.

${ }^{90}$ See supra Section C.III.1.
} 
In conclusion, it can be said that on the one hand, tort law could arguably never entirely fill the gaps that exist in the present German - and international-regulatory structure to tackle climate change. ${ }^{91}$ On the other hand, climate change and tort law are not contradictory as some claim. Dealing with damage to persons or property produced as a result of human activity is "a concern that lies at the heart of tort law." 92 As this Article shows, the current German tort law still leaves room for maneuver when it comes to climate change. We, therefore, might expect to see civil law legal systems evolve to meet the challenges of climate change.

\footnotetext{
${ }^{91}$ John Lowry \& Rod Edmunds, Environmental Protection and the Common Law 51, 70, 75 (2000).

${ }^{92}$ Eduardo Penalver, Act of God or Toxic Torts? Applying Tort Principles to the Problem of Climate Change, 38 NAT. RES. J.
} 563, 569 (1998).

Cite this article: Semmelmayer P (2021). Climate Change and the German Law of Torts. German Law Journal 22, 1569-1582. https://doi.org/10.1017/glj.2021.76 